\title{
PERBEDAAN TINGKAT KECEMASAN PADA PRIMIGRAVIDA DAN MULTIGRAVIDA DI RSIA KASIH IBU MANADO
}

\author{
${ }^{1}$ Debora V.V Mandagi \\ ${ }^{2}$ Cicilia Pali \\ ${ }^{2}$ J.S.V Sinolungan
}

\author{
${ }^{1}$ Kandidat Skripsi FakultasKedokteran Universitas Sam Ratulangi Manado \\ ${ }^{2}$ Bagian Psikologi Fakultas Kedokteran Universitas Sam Ratulangi Manado \\ Email:devivedebora10@yahoo.com
}

\begin{abstract}
Anxiety commonly happen in the time of growing, changing, facing new experiences, accompanies the discovery of self-identity and meaning of life. Pregnancy is growth and development of fetoes intrauterin since conception until the beginning of labour. Anxiety can interferre pregnancy individually. Pregnancy could be one of major stressor that increasing anxiety.The purpose of this study is to determine differences of anxiety in between primigravida and multigravida patient at Maternal and Child (RSIA) Kasih Ibu Hospital, Manado. This study was using Hamilton Anxiety Rating Scale (HARS), total of sampel is 30 patients, consist of 15 primigravida and 15 multigravida. It was obtained that 20 persons from both groups were not had anxiety, in primigravida 30\% and multigravida 36,7\%. That nine persons had mild anxiety consist of 16,7\% primigravida and 13,3\% multigravida, and 1 had moderate anxiety. Conclusion:Use the statistic T-Test it was obtained there is no significance differences occured in between primigravida and multigravida patients at RSIA Kasih Ibu Manado. From primigravida respondences obtained some had moderate and mild anxiety, but most of the respondence did not experiencing anxiety (60\%). Most of the Multigravida respondences in this study did not experiencing anxiety, only four of them had mild anxiety.
\end{abstract}

Keywords: Anxiety, Primigravida, Multigravida.

\begin{abstract}
Abstrak: Kecemasan adalah sesuatu yang normal terjadi dalam pertumbuhan, perubahan, pengalaman baru, dan dapat menyertai penemuan identitas diri dan arti hidup.Kehamilan merupakan pertumbuhan dan perkembangan janin intrauterin sejak konsepsi dan berakhir sampai permulaan persalinan. Secara individu cemas dapat mengganggu. Proses kehamilan, bisa menjadi salah satu stresor yang besar dalam meningkatkan kecemasan khususnya pada wanita hamil. Penelitian ini bertujuan untuk mengetahui perbedaan kecemasan pada ibu hamil primigravida dan multigravida di RSIA kasih Ibu Manado. Penelitian menggunakan kuesioner Hamilton Anxiety Rating Scale (HARS, dengan sampel penelitian 30 wanita (15 primigravida dan 15 multigravida). Berdasarkan hasil penelitian ditemukan 20 orang tidak mengalami cemas, 30\% pada primigravida dan 36,7\% pada multigravida. Sebanyak sembilan orang mengalami cemas ringan, 16,7\% primigravida dan 13,3\% multigravida. Sebanyak satu orang mengalami cemas sedang yaitu pada primigravida.Simpulan:Berdasarkan statistik dengan menggunakan Uji T tidak terdapat perbedaan yang signifikan antara kecemasan yang terjadi pada primigravida dan multigravida di RSIA Kasih Ibu Manado. Dari responden primigravida di RSIA Kasih Ibu Manado, ada yang mengalami kecemasan sedang, kecemasan ringan dan paling banyak tidak mengalami kecemasan (60.0\%). Responden multigravida di RSIA Kasih Ibu Manado, didapat bahwa paling banyak tidak mengalami kecemasan, hanya ada empat responden mengalami kecemasan ringan.
\end{abstract}

Kata kunci: Kecemasan, Primigravida, Multigravida. 
Kecemasan adalah suatu yang normal terjadi dalam pertumbuhan, perubahan, pengalaman baru, dan dapat menyertai penemuan identitas diri dan arti hidup. Kecemasan merupakan suasana perasaan takut terus menerus akan tetapi itu hanya perasaan saja, dan tidak nyata.Gejala cemas bervariasi pada setiap individu. Gejalanya seperti gelisah, pusing, dada berdebar, tremor dan sebagainya, tergantung individu tersebut. ${ }^{1,2}$ Secara individu cemas dapat mengganggu, dan proses kehamilan menjadi salah satu stresor yang besar dalam meningkatkan kecemasan pada wanita hamil. ${ }^{2,3}$

Di USA pada tahun 2004, dari 8000 wanita hamil terdapat $21.9 \%$ yang menderita kecemasan. ${ }^{4}$ Di Indonesia terdapat data wanita hamil yang mengalami kecemasan dalam menghadapi persalinan ada sebanyak 107.000 orang $(28,7 \%)$. Di kabupaten Lampung Tengah ada sebanyak 8.948 ibu hamil, dan yang mengalami kecemasan dalam menghadapi persalinan ada sebanyak 5.355 orang (59,8\%). Dari hasil penelitian sebelumnya pada September-Oktober 2006 terdapat 20 ibu hamil pada trimester III terdapat 15 (75\%) ibu hamil yang menyatakan cemas dalam menghadapi persalinan. Pada bulan Juni-Juli 2009 terdapat 15 ibu hamil pada trimester III dan $10(66,6 \%)$ diantaranya ibu primigravida mengalami cemas dalam menghadapi persalinan. ${ }^{5}$ Selain itu hampir $80 \%$ wanita menolak kehamilannya di trimester I, sering gelisah dan murung, dan terdapat $15 \%$ ibu hamil mengalami gangguan jiwa pada trimester I kehamilannya. ${ }^{6}$

Rumah Sakit Ibu dan Anak Kasih Ibu Manado merupakan salah satu rumah sakit khusus di Manado yang khusus melayani Ibu dan anak. Walaupun belum lama berdiri namun dari letak Rumah sakit ini yang cukup strategis memungkinkan tempat ini mudah dijangkau dan dikenal oleh banyak orang termasuk kalangan di luar kota Manado. Ditambah lagi dengan tenaga medis yang terbaik dan ahli di bidangnya, membuat rumah sakit ini makin dikenal. Sehingga memungkinkan sampel penelitiannya bisa lebih terjangkau. Hal ini membuat penulis tertarik untuk mengetahui bagaimana perbedaan tingkat kecemasan pada primigravida dan multigravida di RSIA Kasih Ibu Manado?

\section{METODE PENELITIAN}

Penelitian ini dilaksanakan di Rumah Sakit Ibu Anak Kasih Ibu Manadopada Bulan Oktober 2012 - Januari 2013. Dengan menggunakan jenis penelitian analitik cross sectional. Populasinya adalah seluruh ibu hamil di RSIA Kasih Ibu Manado, dengan sampel penelitian berjumlah 30 orang terdiri dari 15 wanita primigravida dan 15 wanita multigravida. Penelitian ini menggunakan teknik sampling consecutive sampling, dengan cara pengukur-an untuk mengetahui derajat kecemasan menggunakan Hamilton Rating Scale for Anxiety (HRS-A). Perbedaan kecemasan pada primigravida dan multigravida dianalisis menggunakan Uji T independent.

\section{HASIL PENELITIAN}

Tabel 1. Distribusi Umur dan Pekerjaan dengan Jenis Kecemasan.

\begin{tabular}{ccccccccc}
\hline Jenis & \multicolumn{3}{c}{ Umur (tahun) } & \multicolumn{3}{c}{ Pekerjaan } \\
\cline { 2 - 8 } Kecemasan & $<\mathbf{2 0}$ & $\mathbf{2 1 - 3 5}$ & $>\mathbf{3 5}$ & IRT & PNS & Swasta & $\begin{array}{c}\text { Wira- } \\
\text { swasta }\end{array}$ & $\begin{array}{c}\text { Lain- } \\
\text { Lain }\end{array}$ \\
\hline Tidak & 1 & 18 & 1 & 9 & 3 & 5 & 1 & 2 \\
Cemas & $(100.0 \%)$ & $(64.3 \%)$ & $(100.0)$ & $(45 \%)$ & $(15.0 \%)$ & $(25.0 \%)$ & $(5.0 \%)$ & $(10.0 \%)$ \\
Cemas & 0 & 9 & 0 & 3 & 1 & 2 & 1 & 2 \\
Ringan & $(0.0 \%)$ & $(32.1 \%)$ & $(0.0 \%)$ & $(33.3 \%)$ & $(11.1 \%)$ & $(22.2 \%)$ & $(11.1 \%)$ & $(22.2 \%)$ \\
Cemas & 0 & 1 & 0 & 1 & 0 & 0 & 0 & $0(0.0 \%)$ \\
Sedang & $(0.0 \%)$ & $(3.6 \%)$ & $(0.0 \%)$ & $(100.0 \%)$ & $(0.0 \%)$ & $(0.0 \%)$ & $(0.0 \%)$ & 4 \\
\hline TOTAL & 1 & 28 & 1 & 13 & 4 & 7 & 2 & 4 \\
& $(100.0 \%)$ & $(100.0)$ & $(100.0)$ & $(43.3 \%)$ & $(13.3 \%)$ & $(23.3 \%)$ & $(6.7 \%)$ & $(13.3 \%)$ \\
\hline
\end{tabular}


Tabel 2. Distribusi Trimester dan Kelompok dengan Jenis Kecemasan.

\begin{tabular}{cccccc}
\hline \multirow{2}{*}{ Jenis Kecemasan } & \multicolumn{3}{c}{ Trimester } & \multicolumn{2}{c}{ Kelompok } \\
\cline { 2 - 6 } & I & II & III & Primigravida & Multigravida \\
\hline Tidak Cemas & $0(0.0 \%)$ & $3(15.0 \%)$ & $17(85.0 \%)$ & $9(60.0 \%)$ & $11(73.3 \%)$ \\
Cemas Ringan & $1(11.1 \%)$ & $0(0.0 \%)$ & $8(88.9 \%)$ & $5(33.3 \%)$ & $4(26.7 \%)$ \\
Cemas Sedang & $0(0.0 \%)$ & $0(0.0 \%)$ & $1(100.0 \%)$ & $1(6.7 \%)$ & $0(0.0 \%)$ \\
\hline TOTAL & $1(3.3 \%)$ & $3(10.0 \%)$ & $26(86.7 \%)$ & $15(100.0 \%)$ & $15(100.0 \%)$ \\
\hline
\end{tabular}

Tabel 3. Distribusi Hubungan Suami Istri dan Trimester dengan Kelompok Kehamilan.

\begin{tabular}{ccccccc}
\hline \multirow{2}{*}{ Kelompok } & \multicolumn{3}{c}{ Hubungan Suami Istri } & \multicolumn{3}{c}{ Trimester } \\
\cline { 2 - 7 } & Baik & Sedang & Buruk & I & II & III \\
\hline Primigravida & $14(93.3 \%)$ & $1(6.7 \%)$ & $0(0.0 \%)$ & $0(0.0 \%)$ & $0(0.0 \%)$ & $15(100.0 \%)$ \\
Multigravida & $15(100.0 \%)$ & $0(0.0 \%)$ & $0(0.0 \%)$ & $1(6.7 \%)$ & $3(20.0 \%)$ & $11(73.3 \%)$ \\
\hline TOTAL & $29(96.7 \%)$ & $1(3.3 \%)$ & $0(0.0 \%)$ & $1(3.3 \%)$ & $3(10.0 \%)$ & $26(86.7 \%)$ \\
\hline
\end{tabular}

Tabel 4. Hasil pengujian perbedaan kecemasan Primigravida dan Multigravida.

\begin{tabular}{cccc}
\hline & \multicolumn{2}{c}{ Kelompok } & $\begin{array}{c}\text { Hasil Uji T } \\
\text { Primigravida dan } \\
\text { Multigravida }\end{array}$ \\
\cline { 2 - 3 } & Primigravida & Multigravida & 1,261 \\
Rerata & 12,3 & 10,7 & $\mathrm{p}=0,109$ \\
\hline
\end{tabular}

Hasil pada Tabel tersebut menunjukkan skor kecemasan lebih tinggi pada primigravida dibandingkan dengan multigravida, namun hasil uji $\mathrm{t}$ menunjukan kedua kelompok tidak berbeda bermakna secara statistik karena nilai $\mathrm{p}=0,109>\alpha$ $=0,05$.

\section{BAHASAN}

Berdasarkan hasil didapatkan bahwa kecemasan pada primigravida dan multigravida tidak berbeda bermakna secara statistik, karena nilai $p=0,109>\alpha=0,05$. Dengan demikian berarti hipotesis yang diterima yaitu H0, tidak terdapat perbedaan tingkat kecemasan pada primigravida dan multigravida di RSIA Kasih Ibu Manado, dan otomatis Ha ditolak. Berdasarkan hasil yang didapat, akan dibahas mengenai faktor umur, pekerjaan, hubungan/peran suami dan keluarga terhadap proses keha- milan, dan perasaan serta usia kehamilan, yang ternyata dapat mendukung dalam pengambilan hipotesis diatas.

Pada wanita yang sehat secara psikologi, kehamilan adalah suatu ekspresi rasa perwujudan diri dan identitasnya sebagai wanita. Namun tidak jarang pula adanya perilaku negatif terhadap kehamilan sering kali disertai rasa takut akan kelahiran anak atau peranan menjadi ibu. Namun hal itu tergantung pada riwayat perkembangan peran wanita tersebut. ${ }^{1}$

Berdasarkan hasil penelitian tersebut, didapatkan distribusi umur responden yaitu berkisar 20 tahun hingga 37 tahun dengan jumlah 30 responden. Dari hasil tersebut, ditemukan usia primigravida paling banyak berkisar 25-30 tahun, dan multigravida paling banyak berkisar pada 26-37 tahun. Dikatakan bahwa perilaku manusia dewasa berbeda dengan anak-anak.

Penelitian mengenai primigravida 
muda (usia 20-30 tahun) dan primigravida tua (usia 31-40 tahun) tentang kecemasan dan emosional, didapatkan bahwa primigravida muda sedikit lebih tinggi mengalami kecemasan dibandingkan primigravida tua.,

Pekerjaan dapat memberikan penghasilan dan menambah keuangan keluarga, sehingga ibu hamil pun akan benar-benar siap mengahadapi persalinannya nanti. Dengan penghasilan yang cukup maka pemeliharaan dan pelayanan kesehatan ibu hamil pun dapat terjamin. Ibu hamil dapat mengetahui semua informasi kehamilan dan persalinan yang baik, sehingga dapat menjalani kehamilan dengan aman serta dapat mencegah timbulnya kecemasan. ${ }^{9}$

Menurut ahli teori psikoanalisis, calon anak adalah suatu layar kosong di mana ibu memproyeksikan harapan dan ketakutannya. Dihubungkan dengan penelitian sebelumnya, bahwa terdapat pengaruh yang besar antara peran suami terhadap proses kehamilan istrinya. Dan hasil penelitian tersebut menyatakan hal itu berpotensi mengurangi kecemasan dan dapat membuat ibu tenang dalam menghadapi persalinan. Dinyatakan bahwa keterlibatan suami sejak awal kehamilan sudah pasti akan mempermudah pasangannya dalam menjalani dan menghadapi berbagai perubahan selama kehamilan. Karena bagi laki-laki proses kehamilan merupakan bukti potensinya, dan merupakan suatu dinamika yang memainkan peranan besarnya dalam menjadi ayah. ${ }^{1,10}$

Berdasarkan hasil penelitian dimana terdapat $66.7 \%$ ibu hamil tidak mengalami kecemasan. Hal ini bisa juga dipengaruhi oleh perasaan bahwa kehamilan merupakan suatu ekspresi rasa perwujudan diri dan identitas sebagai wanita, merupakan pengalaman kreatif dan menjadi satu kebanggaan tersendiri sebagai seorang wanita. ${ }^{1}$

Berdasarkan distribusi usia kehamilan pada trimester I ( $<14$ minggu) ada satu responden, trimester II (14 - 28 minggu) ada tiga responden dan trimester III $(>28$ minggu) ada 26 responden. Dinyatakan bahwa dalam proses kehamilan khususnya trimester II dan III terdapat berbagai pro- ses yang umumnya kurang disukai oleh ibu hamil, misalnya quickening (pergerakan janin) dan adaptasi terhadap perubahan habitus tubuh ibu hamil. Namun, beberapa wanita justru mengganggap semua perubahan tersebut sebagai pengalaman yang menggembirakan yang sering kali dibagi dengan pasangannya. Jika merupakan multigravida biasanya adanya quickening membantu saudara kandungnya untuk turut merasakan pergerakan janin dalam kandungan ibunyadan mempersiapkan dia akan kedatangan saudara kandungnya yang baru itu. Dan hal itu turut mengurangi rasa cemas ibu ketika menjalani proses kehamilan. ${ }^{1}$

\section{SIMPULAN}

Berdasarkan hasil penelitian dapat disimpulkan bahwa tidak terdapat perbedaan secara signifikan kecemasan yang terjadi pada ibu hamil primigravida dan multigravida di RSIA Kasih Ibu Manado. Dari responden primigravida yang ada di RSIA Kasih Ibu Manado, didapatkan ada yang mengalami kecemasan sedang, kecemasan ringan dan yang paling banyak tidak mengalami kecemasan (sebanyak 60.0\%). Dari responden multigravida yang ada di RSIA Kasih Ibu Manado, didapat bahwa paling banyak tidak mengalami kecemasan, hanya empat responden yang mengalami kecemasan, itupun kecemasan ringan.

\section{DAFTAR PUSTAKA}

1. Kaplan IH, Sadock JB, Grebb AJ. Kaplan dan Sadock Sinopsis Psikiatri: Ilmu Pengetahuan Perilaku Psikiatri Klinis, alih bahasa: Kusuma W. Jakarta: EGC, 2010; hal.17-21,101.

2. Fidianty I, Noviastuty A. Kecemasan pada wanita hamil pasca abortus. Semarang: Media medika muda Universitas Diponegoro, 2010.

3. Susanti NN. Psikologi Kehamilan. Jakarta: Penerbit buku kedokteran EGC. h.16-25.

4. Grigoriadis S, Meschino DC, Barrons E, Bradley L, Eady A, Fishell A, et al. Mood and anxiety disorders in a sample of 
Canadian perinatal women reffered for psychiatric care. Canada: Arch Women ment health, 2011.

5. Anggraini R. Karakterikstik ibu hamil yang mengalami kecemasan dalam menghadapi persalinan di BPS Uswatun Poncowati Lampung tengah. Lampung tengah; Akademi kebidanan patriot bangsa husada; 2010.

6. Nirwana AB. Wanita \& kehamilan. Psikologi Kesehatan Wanita (remaja, menstruasi, menikah, hamil, nifas, menyusui). Yogyakarta: Penerbit Nuha Medika, 2011; h.73-9.

7. Astria Y. Hubungan karakteristik ibu hamil trimester III dengan kecemasan dalam menghadapi persalinan di Poliklinik Kebidanan dan Kandungan RSUP Fatmawati tahun 2009 [skripsi]. Jakarta:
Universitas Islam Negeri Syarif Hidayatullah; 2009.

8. Mar'at S, Kartono IL. Perilaku Manusia pengantar singkat tentang psikologi. Editor: Polhaupessy FL. 2010.

9. Robb VF, Alder ME, Prescott JR. Do older primigravidas differ from youger primigravidas in their emotional experiance of pregnancy? Journal of reproductive and infant psychology. Routledge. 2005. p.135-41.

10. Tursilowati YS, Sulistyorini E. Pengaruh peran serta suami terhadap tingkat kecemasan ibu hamil dalam menghadapi proses persalinan di Desa Jepat Lor Kecamatan Tayu kabupaten Pati 2007. Jurnal Kesehatan Surya Medika Yogyakarta. 2007. 